\title{
Environmental Benefits of Bt-Cotton Farming: A Case Study
}

\author{
Suneetha Chatla ${ }^{1}$, Sumanth Kumar $\mathbf{K}^{2}$ \\ ${ }^{1}$ Department of Environmental Science, Acharya Nagarjuna University, Nagarjuna Nagar, Guntur, Andhra Pradesh, India - 522510 \\ ${ }^{2}$ Department of Zoology Acharya Nagarjuna University, Nagarjuna Nagar, Guntur, Andhra Pradesh, India - 522510
}

\begin{abstract}
Insect-protected crops like Bacillus thuriegiensis (Bt) cotton are bringing cotton growers new alternatives to broad-spectrum insecticide use in integrated pest management (IPM).The paper analyzes the effect of insect-resistant Bt-cotton farming on pesticide usage and agricultural productivity. To analyze the environmental benefits, and to determine whether the benefits are directly (prime) or indirectly (secondary) related to the growing Bt cotton, a study has been conducted during the year 2009-10 in Guntur district of Andhra Pradesh, a leading southern state of Bt-cotton farming in India. The secondary data such as current literature, conference proceedings, governmental and institutional reports market research etc., were used for the comparative analysis. Ex-post facto research design was used in the present study. The purposive and random sampling methods were adopted for the present investigation. A pre tested and well designed questionnaire was used and personal interview schedule was planned accordingly. The results of Bt-Cotton farming survey revealed that the reduction of application rates of toxic chemicals, decrease of pesticide sprayings to 9.83 percentages compared to sprays in non Bt-cotton farming. The average number of sprays on Bt-Cotton is only 4.36 percentages as the seed is Genetically Modified. Thus, promoting a more widespread diffusion of Bt cotton could amplify the efficiency, and environmental gains. The statistical analsysis established the correlation between the reductions of sprays of pesticides compared to the non-Bt cotton growers. The results also showed significant relation of environmental benefits with the decrease of usage of pollutants that are hazardous to the environment. It is concluded that the technology's sustainability to be monitored using surveillance and monitoring programmes for long term and to assess the scope of occurrences of secondary effects.
\end{abstract}

Key words: Agriculture, Bt-cotton, Pesticides, GM Technology, Environmental benefits.

\section{Introduction}

Agriculture is one of the most ancient and significant sectors of India, the only means of living for almost two-third of the employed class in India (Role of Technology in Rural Development in Agriculture (2016)).

It has occupied almost 43 percent of India's geographical area. It is still an important contributor to India's Gross Domestic Product (GDP) even after a decline in agriculture share and still plays a vital role in the growth of socio economic sector. With a vast population base and its growing demand for food needs, the related burden on agriculture has increased severely extract more agricultural productivity reported by James Hewitt, (2017).

As agriculture evolved into a more productive activity, it became more energy-intensive too. Since agriculture is closely associated with the environment, it has a major impact on land use, soil, water biodiversity and the landscape and the intensive agriculture has disrupted ecological balance. In the process of extracting higher productivity on par with the growing demand, the varieties of crops chosen, though highly-yielding, were found to be prone to epidemic diseases. To protect the crops from the epidemic diseases caused by pests and diseases, it is compiled to use large quantities of pesticides and insecticides (Winfried and Blum, (2013)).

The widespread use and disposal of agriculture pesticides by farmers, large plantations and the general public causes environmental contamination. It is estimated that the 68 percentage of such contamination is a result of agricultural uses, followed by industrial and commercial uses (17percentages) and home and garden application (15percentages). Following release into the environment, pesticides may give rise to different consequences on environment. Pesticides which are sprayed can become airborne and may eventually end up in soil or water. Pesticides applied directly to the soil may be washed off the soil into water or may percolate through the soil to lower soil layers and ground water (USGS, 2016).

The application of agriculture pesticides directly to bodies of water, for weed control or indirectly as a result of run-off from soil or other routes, may lead not only to the build-up pesticides in water, but also cause pollution to the air through evaporation (SAN DIEGO, (2006).). As these pesticides may be broken down or degraded by the action of sunlight, water or other chemicals or microorganisms, this degradation process usually leads to the formation of less harmful residues but in some instances can produce more toxic and hazardous products (Pesticides in the environment (2016). The pesticides become resistance to the degradation by any means and thus remain unchanged in the environment for longer periods of time (Salas et al., 2011). The ones that are most rapidly broken down have the shortest time to move or will otherwise have a diverse effects on humans or other organisms. The ones which last the longest, the so-called persistent pesticides can build up in the environment leading to greater potential for adverse effects on human population ( $\mathrm{Bv}$ and what is a good pesticide (2016)).

\section{Methodology}

The present study was conducted during the year 2009-2010 in the district of Guntur, Andhra Pradesh State India. Guntur 


\section{International Journal of Science and Research (IJSR) \\ ISSN (Online): 2319-7064}

Index Copernicus Value (2015): 78.96 | Impact Factor (2015): 6.391

district, one among the 23 districts of Andhra Pradesh State is inhabited by large number of cotton growing farmers.

\section{Population and sample}

The population for the study covers the cotton farming area of the entire three mandals viz., Amaravathi, Tadikonda and Prathipadu of Guntur district of Andhra Pradesh, India. Based on the cotton farming area and the diversity of problems out of the three mandals (talukas) seven villages from each mandal was identified as sample of the population.

\section{First stage selection - identification of district}

As the present study confined to Guntur district in the state of Andhra Pradesh, selected purposively because the intensity of cultivation of cotton is in the large scale, 75 percent of the entire population was depending on agriculture and the main commercial crop is Bt-cotton. The Guntur district was selected for the sample collection as the first stage selection.

\subsection{Second stage selection - selection of mandals}

From the identified district of Guntur, out of 56 mandals in Guntur district 3 mandals (sub district unit) viz Amaravathi, Tadikonda and Prathipadu were selected purposively based on the cotton growing area. Details of mandals in selected district is furnished.

\section{Third stage selection - selection of respondents.}

The technique of proportionate sampling was adopted and sample size of 200 respondents was limited. The selections of respondents among the mandals and in each villages were presented.

\section{Data collection}

The study involves collection of both primary and secondary data. The primary data was collected from the selected Btcotton farmers with the help of duly pre-tested questionnaire. The secondary data as regard to pesticide consumption over the years and expected consumption were collected in order to get insights on pesticide usage pattern change over the years in the study area. The secondary data was collected from department of agriculture reports, because of their being authenticity. The questions were asked in local language (Telugu) for easy understanding. A great care was taken to obtain the valid and authentic information for the schedule and after completion of day's work. The questionnaire were checked and edited to obtain objective responses.

\footnotetext{
Analysis of data and application of statistical techniques The quantification of qualitative data was done in accordance with the standards laid down and tabulated to draw meaningful inferences. The zero order correlation statistical technique was applied to find out association among different variables. The multiple regression analysis technique was adopted to ascertain the variation. The other statistical techniques applied were frequency, percentage, mean, standard deviation, correlation and multiple linear regressions (MLR).The collected data from the respondents were scored, tabulated and analyzed using the following statistical tools and techniques.
}

\section{Research design}

Ex post-facto and exploratory research design was followed for the present study. A pilot study was conducted prior to main investigation to obtain insights and familiarity to the problem.

\section{Reasons for adopting exploratory design}

- Exploratory research design would help to build up hypothesis which can be tested by planning a higher level of scientific design

- Exploratory research design is flexible design which provides an opportunity for considering different aspects of a problem

- Exploratory research design helps the researcher to draw together the diverse information into a unified interpretation which makes this design as an appropriate procedure for evolving insights

Exploratory research is a type of research conducted because a problem has not been clearly defined. Exploratory research helps to determine the best research design, data collection method and selection of subjects. According to Das (2005), the purpose of exploratory studies is to formulate a problem for a more precise investigation or to develop hypothesis. Here the exploratory study was attempted to enhance the understanding of the benefits of Bt-cotton farming in a more scientific way.

\section{Results}

In addition to the direct control of insects and economic benefits that allow growers to produce a cotton crop more profitably, Bt-cotton also provides numerous secondary benefits. Grower adoption of Bt-cotton has proven to be extremely beneficial to the environment through reductions in broad-spectrum insecticide applications and use of farm machinery (Falck-Zepeda et.al., 1999; Graham Brookes \& Peter Barfoot (2016). The environmental benefits stem directly from a reduction in insecticide applications, which positively affects surrounding ecosystems and associated insect, wildlife, and human populations (Saravanan, S and V Mohanasundaram, (2016).

Julie M. Edge et.al., (2001) stated that the direct benefits documented from using $\mathrm{Bt}$ cotton to control insect pests include reduced use of broad-spectrum insecticide, lower farming risks and production costs, better yields and profitability, expanded opportunities to grow cotton and a brighter economic outlook for the cotton industry. The indirect benefits that arise from the use of the crop primarily stem from the reduction in broad-spectrum insecticide use where Bt cotton is used for pest control. Reducing the use of broad-spectrum insecticides in cotton produces benefits that include increased effectiveness of beneficial arthropods as pest control agents, improved control of non-target pests, reduced risk for farm land wildlife species, reduced runoff of broad-spectrum insecticides, reduced fuel usage, lower levels of air pollution and related waste production, and improved safety of farm workers and neighbors.

It is known that conventional cotton is easily prone to insects and pests, which destroy the whole crop resulting in complete loss to the growers. To protect the crops, the

\section{Volume 6 Issue 7, July 2017




\section{International Journal of Science and Research (IJSR) \\ ISSN (Online): 2319-7064 \\ Index Copernicus Value (2015): 78.96 | Impact Factor (2015): 6.391}

farmers spray synthetic pesticides as many as possible and as much as then could afford financially. It has lead to many unwanted consequences. The non Bt-cotton farmers used to spray when they grew conventional cotton crop. Excessive use of these insecticides and pesticides degrades the ecosystem. Many studies and researches have proved that these synthetic pesticides which were introduced in the mid 1940's however, the regulatory procedures providing approval for their use were limited. Several studies provide that the increasing use of synthetic pesticides would have a serious negative effect on the environment.
The Table 1 reveals that number of sprays targeting bollworms particularly on Heliothis and Pectinophora indicate that $\mathrm{Bt}$ expression might be satisfactory. Number of sprays targeting pink boll worm has not been observed. Sprays targeting sucking pests are not confined at early stage (up to 60DAS) but will be spread throughout the crop growth period. The results pertaining pesticides usage pattern was presented in Table 2. and Table 3. It indicated that the average number of sprays reduced to 4.36 from 9.83 by adopting Bt technology. Nearly 80 percent of sprays were targeted bollworms before introduction of Bt technology in cotton. The sprays in Bt-cotton targeted sucking pest complex.

Table 1: Pesticide usage pattern in Bt cotton farmers in Guntur district

\begin{tabular}{|c|c|c|c|c|}
\hline S.No & Duration & Total no of sprays & $\begin{array}{c}\text { Percentage of insecticides against } \\
\text { sucking pests }\end{array}$ & Percentage of pesticides against sucking pests \\
\hline 1 & Up to 60 DAS & 395 & 100 & 100 \\
\hline 2 & $60-90$ DAS & 212 & 60 (35\% for Spodoptera targeted $)$ & 95 (5\% bactericide) \\
\hline 3 & $90-120$ DAS & 182 & 100 & 83.7 (16.7\% fungicides) \\
\hline 4 & After 120 DAS & 84 & 100 & 66.7 (16.6 bactericide and $16.7 \%$ fungicides) \\
\hline & Average & 4.36 & & \\
\hline
\end{tabular}

Table 2: Pesticide usage pattern in non Bt cotton farmers in Guntur district

\begin{tabular}{|c|c|c|c|c|}
\hline S.No & Duration & Total no of sprays & Percentage of insecticides against Bollworms & Percentage of pesticides against Bollworms \\
\hline 1 & Up to 60 DAS & 428 & 48 & 66 \\
\hline 2 & $60-90$ DAS & 593 & 89 & 95 (5\% bactericide) \\
\hline 3 & $90-120$ DAS & 548 & 92 & 78.3 (21.7\%fungicides) \\
\hline 4 & After120 DAS & 397 & 100 & 66.7 (16.6 bactericide and 16.7\% fungicides) \\
\hline & Average & 9.83 & & \\
\hline
\end{tabular}

Table 3: Plant protection chemicals - consumption from 1998-99 to 2008-09 (Technical Grade in MTs)

\begin{tabular}{|c|c|c|c|c|c|c|c|c|c|c|c|c|c|}
\hline $\begin{array}{c}\text { S. } \\
\text { No }\end{array}$ & Name of the Chemicals & $\begin{array}{c}1998- \\
1999\end{array}$ & $\begin{array}{c}1999 \\
2000\end{array}$ & $\begin{array}{c}2000- \\
2001\end{array}$ & $\begin{array}{c}2001- \\
2002\end{array}$ & $\begin{array}{c}2002- \\
2003\end{array}$ & $\begin{array}{c}2003 \\
2004\end{array}$ & $\begin{array}{c}2004- \\
2005\end{array}$ & $\begin{array}{c}2005- \\
2006\end{array}$ & $\begin{array}{c}2006- \\
2007\end{array}$ & $\begin{array}{c}2007- \\
2008\end{array}$ & $\begin{array}{c}2008- \\
2009\end{array}$ & $\begin{array}{c}\% \text { change between } \\
1998-99\end{array}$ \\
\hline 1 & Synthetic Pyrethroids & 64 & 60 & 59 & 120 & 54 & 27 & 28 & 13 & 4 & 4 & 3 & 4.69 \\
\hline 2 & Other Insecticides & 1020 & 1012 & 1002 & 2096 & 674 & 451 & 439 & 108 & 42 & 47 & 38 & 3.73 \\
\hline 3 & Weedicides & 128 & 121 & 134 & 84 & 43 & 23 & 26 & 11 & 5 & 10 & 4 & 3.13 \\
\hline 4 & Fungicides & 423 & 421 & 441 & 361 & 177 & 142 & 167 & 20 & 9 & 1 & 7 & \\
\hline 5 & Rodenticides & 18 & 17 & 16 & 20 & 12 & 6 & 6 & 10 & 4 & 3 & 3 & 1.65 \\
\hline 6 & Neem based pesticides & - & - & - & - & - & - & - & - & - & 2 & 1 & 16.67 \\
\hline 7 & Plant growth regulator & - & - & - & - & - & - & - & - & - & 5 & 2 & - \\
\hline & TOTAL & 1653 & 1631 & 1652 & 2681 & 960 & 649 & 666 & 162 & 64 & 72 & 58 & - \\
\hline
\end{tabular}

Source: Agriculture action plan (2009-10)

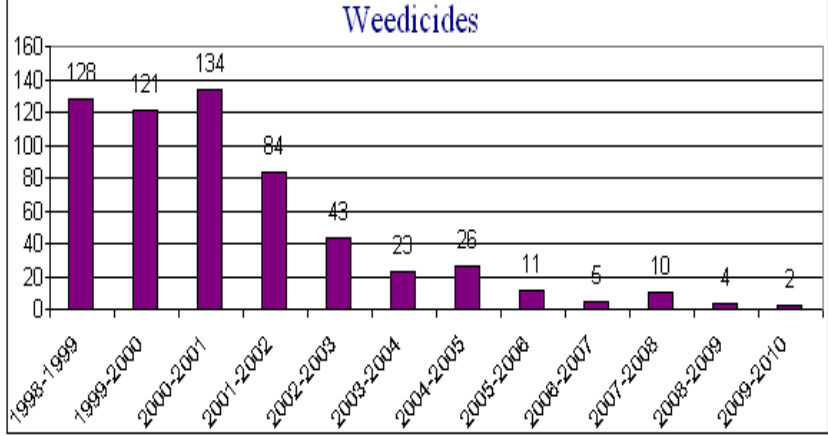

Figure 1: Consumption of Weedicides

It was observed from the (Fig.1) that weedicides usage in cotton farming was fluctuated during 1998-2001 between 128 tons and -134 tons. Later, it recduced to 84 tons during 2001-02 and registered a study decline which had been recorded till 2009-10 with slight fluctations during the years from 2005 to 2008 . The decline in weedicide consumption could be attributed to Bt-technology adoption.

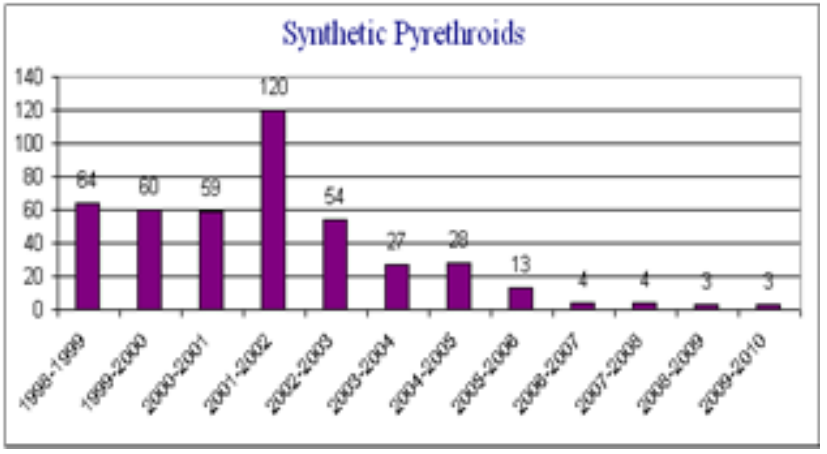

Figure 2: Consumption of synthetic pyrethroids

It was proved (Fig.2) that the usage of synthetic pyrethroids was reduced from 2002-03 onwards. During the years from 1948 to 2001, there had been fluctuations but from 2002 on wards the reduction has been diminished from 120 tons to mere 3 tons during 2009-10. It was clearly observed that the usage of synthetic pyrethroids had gone to an extreme peak stages during 2000-01 which touched 120 tons during the 


\section{International Journal of Science and Research (IJSR) \\ ISSN (Online): 2319-7064}

Index Copernicus Value (2015): 78.96 | Impact Factor (2015): 6.391

two preceded crop years and then drastically declined from 134 tons to 60 tons in the very next year (2001-2002), because of Bt-cotton introduction.

\section{Discussion and Conclusion}

Bt cotton can substantially reduce the number of pesticide sprayings, which can provide significant environmental benefits (Saravanan, (2016) and Kranthi, (2012). A number of studies have demonstrated that insecticide sprays are reduced by using Bt cotton (Carpenter et.al. 2002; Edge et al., 2001; James, 2002; Julian Witjaksono et al.,2014).

The use of Bt cotton in place of conventional systems can positively impact non target organisms (NTOs) and beneficial organisms by preserving populations (Head et.al, 2001; Smith, 1997; Xia et.al., 1999; ZHAO Cai-yun et al., (2016)). It is also compatible with integrated pest management initiatives (Benedict \& Altman, 2001). In addition, Bt-cotton farming adoption can provide secondary positive environmental impacts such as a) saving on raw materials needed to manufacture chemical insecticides b) conserving fuel oil required to manufacture, distribute, and apply such insecticides and c) eliminating the need to use and dispose of insecticide containers (Leonard and smith, 2001).

Major environmental benefits could be attributed to decrease of 50 percent in the number of insecticide sprays per season, which in turn reduced insecticide residues that could potentially runoff into watersheds and aquifers. A decrease of 14 sprays in China (from 28 to 14 sprays), 7 in South Africa, and 2 in USA. Global insecticide savings attributed to Bt cotton in 2001 were $10,500 \mathrm{MT}$ of insecticide active ingredient equivalent to $13 \%$ of the $81,200 \mathrm{MT}$ (a.i) of all cotton insecticides used globally in 2001. According to department of agriculture Andhra Pradesh State, India during 2001-02 the quantity of plant protection chemicals utilized in cotton growing area was 2681 tons technical grade. It was reduced to 52 tons during the 2008-09 respectively.

The important aspects of the environmental debate surrounding the introduction of G.M. crops and that in their potential reduction in pesticides use in the European Union $50 \%$ reduction of pesticide spraying resulting from the introduction of Bt-cotton varieties. (Phipps and Park, 2008). Hence, it is important to know the reduction in pesticide use can be linked to improve the surrounding environment.

Qaim and Alinde (2005) reported that they had empirically analyzed the effects of $\mathrm{Bt}$ cotton on pesticide use and productivity in Argentina. The farm survey revealed that the Bt technology lead to a considerable decline in pesticide application rates. On an average $\mathrm{Bt}$ technology adopting farmer use $50 \%$ less insecticide on their Bt plots than on plots grown with conventional cotton. All most all of these reductions occur include in highly toxic chemicals, with concomitant positive effects for the environment. Moreover, Bt cotton adopters benefit from significantly higher yields compared to conventional cotton due to insufficient pest control methods. It was also observed from the present study that with introduction of Bt-cotton, number of sprays reduced to 4.36 from 9.83 which could be attributed to the environmental benefits associated with introduction of Btcotton technology.

Bt-cotton farming has reduced pesticide sprayings by 172 million $\mathrm{Kg}$ and reduced the environmental toot print associated with pesticide use by 14 percent. The Bt technology has also significantly reduced the release of green house gas emissions from agriculture which is equivalent to removing 5 million cars from roads (Brookes and Barfoot, 2006). GM crops have contributed to a significant reduction in global environmental impact of production agriculture. Since1996, the use of pesticide was reduced by 224 million $\mathrm{kg}$ of active ingredient $(6.9 \%$ reduction) and the overall environmental impact associated pesticide use on these crops was reduced to 15.3 percent. In absolute terms the largest environmental gain has been associated with the adoption of Bt cotton.

Phipps and Park (2002) stated that despite the limitations in the analysis, the overall complexities of the debate that the authors believed the GM technology has the potential to markedly reduce overall pesticide use. Further, if less chemical is used and the number of spray applications are reduced, there would be a considerable saving in support of energy required for crop production. According to Kline, a New Jersey based consulting firm, analyzed the future trends in pesticide use in the USA during the year 2009. Their analyses of the market indicated that by 2009 , Bt and insect protected crops would contribute to annually 20 million and 6 million $\mathrm{kg}$ of herbicide and insecticide active ingredient respectively.

In a recent survey, conducted in the USA showed that about $75 \%$ of people surveyed, said that they approved the use of biotechnology to produce insect protected crops which in turn reduced the use of pesticides. This is supported by studies carried out in Canada by the University of Guelph. According to their studies the public was offered the choice of either buying conventional or GM sweet corn and potatoes.

A list of sprays used on the produce was clearly visible for the public to see. Under these circumstances $60 \%$ of the public preferred to buy GM rather than conventional produce. The authors of these studies expressed their interest to observe the attitude of Europe Union consumers towards G.M. and Non G.M. varieties. From all these, the expected hypothesis "the adoption of Bt-cotton farming will result in positive environmental effects, prevents the environmental pollution and stabilizes the eco system", has been evidently proved to be true.

\section{References}

[1] Benedict, J.H. and D.W. Altman., 2001 Commercialization of transgenic cotton expressing insecticidal crystal protein. Ag Bio Form 11:137-201.

[2] Carpenter, J., Felsot, A., Goode, T., Hammig, M., Onstad, D., \& Sankula, S., 2002. Comparative environmental impacts of biotechnology-derived and traditional soybean, corn, and cotton crops (CAST: I189). Ames, IA: Council for Agricultural Science and

\section{Volume 6 Issue 7, July 2017 www.ijsr.net}




\section{International Journal of Science and Research (IJSR) \\ ISSN (Online): 2319-7064}

Index Copernicus Value (2015): 78.96 | Impact Factor (2015): 6.391

Technology.

http://www.cast-

science.org//cast/biotech/pubs/biotech-cropsbenefit.pdf, accessed on 29.10.2010

[3] Edge, J.M. Benedict, J.H., Carroll, J.P., and Reding, H.K. 2001. Bollgard cotton: An assessment of global economic, environmental and social benefits. Journal of Cotton Science, 5(2), 121-136. Accessed on line http://journal.cotton.org/2001/issue02/Art_08.pdf dated: 11.09.2009

[4] Head, G, Freeman, B., Mina, B., Moar, W., Ruberso, J., and Turnip-seed, S. 2001. Natural enemy abundance in commercial bollgard and conventional cotton fields. Proceedings of the beltwide cotton conference Memphis, TN: National Cotton Council. 2: 796-798.

[5] James, C. 2002. Global review of commercialized transgenic crops: 2001 (ISAAA Brief No. 26-2001). ITHACA, NY: International Service for the acquisition of agri-biotech applications accessed on date: 29-102010 http://www.isaaa.org/Publications/breifs/briefs_26.htm

[6] Julie M. Edge, John H. Benedict, John P. Carroll, and Keith Reding H. 2001. Contemporary issues, bollgard cotton: an assessment of global economic, environmental, and social benefits. The journal of cotton science: $\quad \mathbf{5}: 121-136$

[7] Leonard, R and Smith, R. 2001. IPM and environmental impacts of Bt Cotton: A new era of crop protection and consumer benefits. Agrl. Sci. 3: 15-26

[8] Qaim Matin. and Janvry Alain De., 2005. Bt cotton and pesticide used in Argentina: economic and environmental effects; environment and development economic 10:179-200.

[9] Smith, R.H. 1997. An extension entomologist's 1996 observations of Bollgard (Bt) technology. Proceedings of the Belt wide cotton conference. Memphis, TN: National Cotton Council 2: (856-858).

[10] Brookes G. and Barfoot P. 2006. Global Impact of Biotech Crops: Socio-Economic and Environmental Effects in the First Ten Years of Commercial Use. AgBioForum. 9 (3):139-151.

[11]Phipps, R.H., and Park, J.R., 2002. Environmental benefits of genetically modified crops: global and European perspective on their ability to reduce pesticide use. Journal of Animal and Feed Science, 11:1-18.

[12] Xia, J.Y., Cui, J.J., Ma, L.H., Dong, S.X., and Cui, X.F. 1999. The role of transgenic Bt cotton in integrated insect pest management. Acta Gossypii Sim, J.Jiangsu Agric.Sci. 11: 57-64.

[13] Phipps, R.H., and Park, J.R., 2008.

[14] Winfried E.H.Blum (2013). Soil and Land Resources for Agricultural Production: General Trends and Future Scenarios-A Worldwide Perspective.International Soil and Water Conservation Research, Vol 1 (3): 1-14.

[15]Role of Technology in Rural Development in Agriculture (2016)).

[16] James Hewitt, (2017).Head of Science \& Innovation, Hintsa Performance.

[17] USGS has on-line fact sheets about pesticides in groundwater and pesticides in the hydrologic system. (2016). U.S. Department of the Interior| U.S. Geological Survey URL: http://water.usgs.gov/edu/pesticidesgw.html Page Contact Information: Howard Perlman.
[18] Pesticides in the environment (2016). University of Kentucky College of Agriculture. Pesticide Certification Study Site.

[19] SAN DIEGO, (2006). Sustainable landscape guidelines, A Watershed Approach to Landscaping.

[20] Salas, B.V., Duran E.I.G. and Wiener, M.S. (2011). Impact of Pesticides Use on Human Health in Mexico: A Review, Reviews on Environmental Health, vol 15 (2).

[21] Bv and what is a good pesticide (2016).things you need to know about "pesticides" and "good pesticides".

[22] Graham Brookes \& Peter Barfoot (2016) Environmental impacts of genetically modified (GM) crop use 1996 2014: Impacts on pesticide use and carbon emissions, GM Crops \& Food, 7:2: 84-116.

[23] Saravanan, S and V Mohanasundaram, (2016). Development and Adoption of Bt Cotton in India: Economic, Environmental and Health Issues. 20:13.

[24] Saravanan, S (2016). Bt cotton in India, pesticide use and environmental. impact in IndiaInternational Journal of Applied Research ; 2(7): 829-832.

[25] Kranthi K. R. (2012). Bt Cotton Q\&A Questions and Answers, INDIAN SOCIETY FOR COTTON IMPROVEMENT (ISCI), MUMBAI.

[26] Julian Witjaksono, Xiaowen Wei, Suchun Mao, Wankui Gong, Yabing Li, Youlu Yuan, (2014) "Yield and economic performance of the use of GM cotton worldwide over time: A review and meta-analysis", China Agricultural Economic Review, Vol. 6 (4):616643.

[27]ZHAO Cai-yun, YU Xiao-dong, LIU Yong-bo , LI Junsheng, (2016). Effects of insect-resistant transgenic cotton on ground-dwelling beetle assemblages (Coleoptera), Journal of Integrative Agriculture, 15(2): 381-390. 